\title{
Jefferson Davis: from President to Place-Name
}

\author{
PHILIP C. KOLIN
}

\begin{abstract}
$\mathbf{T}$
HE NAMES OF THE presidents have had a profound effect, political and patriotic, upon our country. H. L. Mencken unerringly states that "Washington, of course, is the most popular of American placenames." 1 Looking just at the names of American counties, 31 honor George Washington, 26 pay tribute to Jefferson, ${ }^{2}$ and numerous towns and hamlets named for Lincoln dot the map of America. The onomastic influence of one of Lincoln's contemporaries, in fact his rival in office, has not, unfortunately, been studied. Jefferson Davis, the first and only President of the Confederate States of America, has exerted a tremendous influence upon names, place and personal, primarily in the southern half of the United States. The commemorative uses of his name are part of an interesting cultural and political heritage. This paper will explore the incidence and significance of Jefferson Davis' name for counties, roads, schools, parks, hospitals, and miscellaneous other places and persons. Before turning to these uses of Davis' name, however, I would like to provide an onomastic sketch of the man and his presidency.
\end{abstract}

From birth Jefferson Davis himself was surrounded by names presidential. Davis was born June 3, 1808, in Christian County, Kentucky, just nine months after and 80 miles away from the birth of Abraham Lincoln. ${ }^{3}$ Davis' father, Samuel, was a strong admirer of Jeffersonian ideals and named his son in honor of the famed Virginian president. Elisabeth Cutting speculates that the boy was really named Thomas Jefferson Davis: "It was a departure from their custom[Davis' parents]

1 H. L. Mencken, The American Language, 4th ed. abridged by Raven I. McDavid, Jr. (New York: Alfred A. Knopf, 1963), p. 651.

2 Joseph Nathan Kane, The American Counties (Metuchen, New Jersey: Scarecrow Press, 1972), p. 13.

3 For details about Davis' life, consult Hudson Stroude, Jefferson Davis, 3 vols. (New York, 1955-1964). 
of using only Biblical names. There is a record of 'T. J. Davis' and those who find interest in parallels like to point out that the T. was dropped in his case as was the Thomas in Woodrow Wilson's name."4 We do know that the tenth and last child of the Davis family was given an appropriate if strange middle name of Finis to symbolize his parents' last attempt to bring children into the world. ${ }^{5}$ But clearly Davis did not use either an initial $\mathrm{T}$. or a middle $\mathrm{F}$. (History ironically records a Jefferson Columbus Davis, a Union general who rode with Sherman to the sea and was at the battle of Chickamauga.) As a young child, he was called "Little Jeff," a name later given to his own small son, although the President of the Confederacy personally disliked being called "Jeff Davis." 6 The first school Jefferson Davis attended, too, must have reminded him of the presidency-the Jefferson Academy in Natchez.

After attending Transylvania University and West Point, Jefferson Davis saw service in the Black Hawk War in Wisconsin, a state "that proudly claims Jefferson Davis to have been the first white man to direct log-rafting through the Dells, or to have seen the future site of Madison when as a Lieutenant under General Zachary Taylor and Winfield Scott, he explored the vast wilderness frontier, during the campaigns of the Indian wars."7 Davis later married Sarah Knox Taylor, the daughter of the twelfth President of the United States. A decade later, Davis became famous in the Mexican War, fighting valiantly at Metamoras, Palo Alto, and, after receiving a serious injury at Buena Vista, he was known as "the hero of Buena Vista."8 He represented Mississippi in the Congress and was its U.S. Senator. Davis was also a distinguished statesman. As Secretary of War in Franklin Pierce's cabinet, Davis initiated a survey of a practical route to the Pacific Coast, a feat leading to the Jefferson Davis Highway (see below).

With a career this glorious, Davis was a highly likely choice to be President of the Confederate States of America. And it was inevitable that the names and honors of other administrations would characterize his. The Stars and Bars replaced the Stars and Stripes. Davis took the oath of office in Montgomery, Alabama, on February 18, 1861, and lived in a building known as "The White House of the Confederacy,"

\footnotetext{
4 Elisabeth Cutting, Jefferson Davis, Political Soldier (New York, 1930), pp. 11-12.

5 Stroude observes that because the Davis' eldest son Joseph was 23 when Jefferson was born "it seemed unlikely that Jane Davis would ever bear another child. Perhaps for this reason the baby Jefferson was given Finis for a middle name" $(I, 3)$.

6 Stroude, vol. 1.

7 Quoted from Jefferson Davis Highway (Richmond, Virginia: United Daughters of the Confederacy, 1960), pp. 55-56, and hereafter cited as JDH.

8 Burke's Presidential Families of the United States of America (London, 1975), p. 590.
} 
appropriately located at 626 Washington Street. ${ }^{9}$ The same prestige associated with Washington was again attached to Davis later in his life when he came to occupy Beauvoir, his last home, affectionately referred to as "The Mount Vernon of the Confederacy."10 And like Washington, too, numerous stories were circulated about where Davis slept when he retreated south from the Confederacy's last capital in Richmond. Two interesting articles in South Carolina newspapers"Jefferson Davis Slept Here-and Here-and Here" and "Jefferson Davis spent night in Laurens County"-substantiate the persistence of a nation's curiosity about its presidents' nocturnal accommodations, ${ }^{11}$ even if Davis' were most clandestine.

As President, Davis corresponded with the world's rulers and dignitaries. In 1862, William Gladstone praised President Davis for creating a new country, a Confederate nation. ${ }^{12}$ His Holiness Pope Pius IX addressed Davis as the "illustrious and honorable president."13 Another religious man, Father Ryan, an Irish priest, became known as "The Chaplain of the Confederacy," 14 thus giving the Davis regime a religious leader.

If Davis was not called "the Father of his Country," his youngest daughter, Varina, fondly known as Winnie, was hailed as "The Daughter of the Confederacy." Davis himself was and has been acclaimed with such heroic titles as "Chief Executive," "Commander-in-Chief," "Leader of the South," "American Patriot"15 and "The Great Chieftain." During the War years, Davis was a source of inspiration to his troops. One patriotic command, now gracing the martial gray stationery of the Old Court House Museum in Vicksburg, must have been typical of the South's respect for its President: "Stand firmly by your cannon./Let your ball and grapeshot fly;/Trust in GOD and Davis,/But 'keep your powder dry'."16 Other groups using explosives also honored the South

9 Joseph Nathan Kane, Famous First Facts (New York: Wilson, 1964).

10 Quoted in World Book Encyclopedia (Chicago, 1956), IV, 1884.

11 James P. Sloan, "Jefferson Davis Slept Here-and Here-and Here: An Account of South Carolina's Hospitality To The President of The Confederacy," The State Magazine, January 31, 1954, pp. 1-3; Don Babb, "Jefferson Davis spent night in Laurens County," The Laurens Advertiser, July 17, 1972.

12 Quoted from Frank E. Vandiver, "Jefferson Davis-Leader Without Legend," The Journal of Southern History, 43 (February 1977), 3-18, here 15.

13 Quoted from Jefferson Davis Ex-President: A Memoir by his Wife [Varina Davis] (New York: Belford Company, 1890), II, 446.

14 A modern edition of Father Ryan's poetry is Selected Poems of Father Ryan, edited by Gordon Weaver (Jackson: University and College Press of Mississippi, 1973).

$15 \mathrm{JDH}, \mathrm{p} .3$.

16 Gordon A. Cotton is the Director of the Old Court House Museum-Eva W. Davis Memorial in Vicksburg and wrote to me using this stationery. 
and Davis. George R. Stewart notes: "In the western mining regions, Northerners and Southerners sank most of their differences in the common frenzy of goldhunting. In one district there was a General Grant mine, along with a General Lee. Although the men were mostly northern they allowed mines to be named the Jeff Davis, the Stonewall Jackson, the Confederate State, and the Bonnie Blue Flag." 7

Tributes to Davis after his death also call to mind honors bestowed upon other presidents. A 351-foot high obelisk-the Jefferson Davis Monument-in Fairview, Kentucky, near Davis' birthplace, looks a great deal like the Washington Monument in Washington, D.C. Numerous statues of Davis are found in the South, and the Jefferson Davis Statue is located in Statuary Hall in Washington, D.C., given by Davis' home state of Mississippi. Memorial markers honoring the President are found from Virginia to Washington state along the Jefferson Davis Highway. This famous road and the man who sponsored it are commemorated in a song worth quoting in full because it symbolizes Davis' South, particularly his native state:

The Jefferson Davis Highway

Tune: "There's A Long, Long Trail A Winding"

1. There's a long, long trail a winding

Through the land of the U. D. C.;

'Tis the Jefferson Davis Highway

And it calls to you and me.

We never will stop working

'Til all our dreams come true,

'Til the day that I go riding down that

long, long trail with you.

2. And the trail is long and winding, and the road is fair to see

'Tis the Jefferson Davis Highway, and 'twas built by you and me.

We built it with hope and courage, and with love and harmony,

This long, long trail that's winding, through the land of the U. D. C.

17 George R. Stewart, Names on the Land (Boston: Houghton Mifflin, 1958), p. 300. In his American Place-Names (Oxford, 1970) Stewart cites a Jeff Davis Creek, Oregon, which he says gives "evidence of a naming at the time of the Civil War by settlers favoring the Confederacy" (p. 226). 
3. There's a beautiful trail a winding through the

State of Mississippi

'Tis the Jefferson Davis Highway, road of the U. D. C.

With its markers and tall pine trees, its lovely scenery

Its forests, hills and rivers, a wonderful sight to see

'Tis the South's 'Road of Remembrance' and it calls to you and me. ${ }^{18}$

Not all the songs about or names applied to Davis were, of course, praiseworthy. As James Redpath, a noted abolitionist and foe of Davis', remarked: "There are two Jefferson Davises in American history." The one is the idealized Southern statesman and loyal leader. The other, Redpath goes on to say, was

a conspirator, a rebel-a traitor-the fiend of Andersonvillehe is a myth evolved from the hell and smoke of cruel war, as purely imaginary a personage as is Mephistopheles. ${ }^{19}$

Davis was branded as a destroyer of the Union, the man who led a civil war, a name odious to some Southerners who prefer calling the conflict the Second War for Independence, ${ }^{20}$ the Confederate War, or, as Davis himself referred to it, the War Between the States. ${ }^{21}$ Northerners cried for vengeance, and to the tune of "John Brown's Body Lies A Moulderin' in the Grave" sang "Hang Jeff Davis From A Sour Apple Tree." Davis was even accused of plotting Lincoln's assassination. After the War, he was imprisoned for years in Fort Monroe and did not regain United States citizenship until quite recently (April 27, 1977), thanks to a bill introduced by a Yankee Senator, Mark Hatfield of Oregon. (It is not hard to see how Davis was considered by some to be a martyr for his cause.)

Davis was maligned by Southerners as well as by Yankees. Professor Frank E. Vandiver, an authority on Davis, astutely points out how, in early histories by Edward Alfred Pollard and others, Jefferson Davis became responsible for all that went wrong with the War. Vandiver observes: "His enemies, Union and Confederate, used his errors as the

18 I would like to thank Michelle Hudson at the State of Mississippi Department of Archives and History for calling my attention to this song.

19 Quoted in $J D H$, p. 12.

20 One of my students, Henry Spear, insists he always heard the Civil War called this.

21 For a discussion of various names for the Civil War, see Raven I. McDavid, Jr. and Virginia G. McDavid, "The Late Unpleasantness: Folk Names for the Civil War," Southern Speech Journal, 34 (Spring 1969), 194-204. 
stuff of myth. He symbolized everything tawdry the times and the Pollards required-sinful southern arrogance, haughty Confederate incompetence. An image he had carefully fashioned throughout his life was ignored by northerners needing a traitor and by southerners needing a scapegoat." 22 For Vandiver, Jefferson Davis had become "a kind of southern Barabbas," someone on whom the South could lay blame. $^{23}$ One 1923 history, Jefferson Davis, President of the South, ${ }^{24}$ shows from its title that Davis is treated as a regional figure, and his loss was a region's as well. Jefferson Davis, then, who had been epitomized as the "Southern Gentleman" and "the Gentleman incarnate" has also been attacked as a perfidious traitor and an incompetent leader. Ironically, the latest assessment of Davis the man is that he is "a gentleman revolutionary." 25

As the following place-names reveal, the use of Davis' name has been limited in both space and time. Primarily, though not exclusively, found in the South, places honoring the President of the Confederacy were so named after the Reconstruction. The Union troops stationed in the South and the carpetbagging Yankees who accompanied them would hardly allow southerners loyal to the old cause to erect new edifices in honor of a defeated traitor. ${ }^{26}$ Hence, counties, schools, or roads having Davis' name do not date much before 1900, although there are some exceptions to be sure. And with the advancement of the Civil Rights movement we do not find many places named after Jefferson Davis, a name inflammatory to some groups who associate him with violence and white supremacy. In fact, in a short story entitled "Neighbors" by Diane Oliver (first published in The Sewanee Review in the spring of 1966), a small black child, Tommy, is ready to attend the all-white Jefferson Davis School amidst a great deal of racial trouble. While there are some new roads and schools named after Davis, ${ }^{27}$ many older buildings and streets which were named for him are being torn down by time and to make room for new construction.

There are three counties and one parish named after Davis, which at first may seem like a small number. But considering the historical facts, this is not surprising. By 1865, most of the counties east of the

22 Vandiver, p. 16.

23 Ibid.

24 Hamilton J. Eckenrode, Jefferson Davis, President of the South (New York, 1923).

25 Vandiver, p. 16.

26 John Algeo informs me that the playing of Dixie on the University of Georgia campus is still outlawed (personal letter dated March 11, 1977).

27 If Hattiesburg, Mississippi is typical, a street in a new subdivision (last ten years) has been named after Davis. 
Mississippi were already chartered and named. Moreover, as we saw, Northern opposition to anything honoring the old cause and some Southern sentiment against Davis doubtless prevented major political units like counties being named after the defeated Confederate President. Those counties and the parish bearing Davis' name, therefore, were generally created from divisions in previously existing large counties and generally were named long after the Reconstruction.

Jeff Davis County ${ }^{28}$ in southwest Texas is something of an exception. It was created in 1887 , some 20 years after the Civil War and two years before Davis died, and hence is one of the first place-names cited in this paper honoring Davis. Texas has paid tribute to no fewer than 18 Confederate soldiers and statesmen by naming counties after them. ${ }^{29}$ The immigration into Texas of Southerners who lived farthest east accounts for this patriotic nomenclature. Jeff Davis County not only honors the President of the Confederacy but memorializes Pierce's Secretary of War who was responsible for a route to the Pacific. Fort Davis, the county seat and highest town in Texas $(5,050$ feet above sea level), and the Davis Mountains also are named in honor of Davis.

The years 1905-1906 appear to set a record for naming counties in honor of Davis, for this is when Jeff Davis County, Georgia and Jefferson Davis County, Mississippi were formed. Both were chartered after splitting from other counties. Jeff Davis County, Georgia was formed from sections of neighboring Appling and Coffee Counties. The Georgia county honoring Davis is found in the southwest corner of the state. "One story is that Davis and his cabinet met there for the last time," 30 a likely possibility, and what was an occasion of grief gives rise to a new honor to the President of the Confederacy. Jefferson Davis County, Mississippi was created from parts of nearby Lawrence County and celebrates the memory of a native son. It is located in south central Mississippi and has its county seat in Prentiss, also the home of Prentiss Technical Institute, a black school.

The last large political area to be named for Davis is Jefferson Davis Parish, Louisiana, found in the southwestern part of the state and having its parish seat at Jennings. ${ }^{31}$ Together with Beauregard and

\footnotetext{
28 Some places have preferred to use officially Jeff Davis rather than Jefferson Davis and even those counties or schools using the full form of the President's name sometimes shorten their name to Jeff Davis.

29 Z. T. Fulmore, The History and Geography of Texas as Told in County Names (Austin: E. L. Steck, 1915), p. 244.

30 Personal letter from John Algeo, dated March 11, 1977.

31 Sometimes it is difficult to determine whether a place has been named for the President of the Confederacy or the County which bears his name, or both. In Jeff Davis County, Louisiana
} 
Allen Parishes, Jefferson Davis Parish was created from parts of the Imperial Calcasieu Parish in 1913. For 16 years prior to the formation of the Parish the citizens of the area had been arguing for a separate parish. The existing parish seat was at Lake Charles, a distance too far for the residents of the area to go to, and since Lake Charles was the most populous town in Imperial Calcasieu, it always selected the one state representative of the parish. Finally, on June 12, 1912, Governor Luther B. Hall approved the creation of Jefferson Davis Parish which took effect on January 1, 1913. The Southern patriotism, reflected in other parish names, can also be seen in the high regard the people of Louisiana have for Jefferson Davis.

Jefferson Davis has lent his name to schools more than to any other institution or place. One of my colleagues at Southern Mississippi, an eminent historian of the American South, remarked that quite possibly every town below the Mason-Dixon line had a school named in honor of Davis. Unfortunately, the facts do not back him up, but for some areas of the South his assessment is accurate. As the place where children learn about manners and obligations, history and citizenship, the schools in the South inevitably were named to honor her leading sons, Davis prominent among them. While I cannot present conclusive details about all the schools which bear Davis' name, the following examples do suggest how widely spread Davis' influence is in education-from the grammar school to the college.

While no four year college or senior college is named after Davis, there is at the Medical College of Virginia, in Richmond, "a Chapel to the Memory of Jefferson Davis-(cost approximately $\$ 30,000.00)$-as a Centennial Memorial in the very vicinity where Davis served as President of the Confederate States." 32 The tribute here is well-deserved, for the Medical College was the only Confederate medical school to remain open for the entire War and supplied needed doctors for the Confederate army and navy. At Transylvania University, Lexington,

(Jennings), for example, there are a number of service-oriented facilities which bear the name Jeff Davis-Abstract Corporation, Bank and Trust, Bureau Adjustment Service, Cable T.V. Incorporated, Community Action, Consumer Information and Housing, Counciling, Country Club, Insurance Corporation, Rentals, Teachers Federal Credit Union, and Wholesale Corporation-and which appear to be named for the county directly. Yet in the same town, we find the Jefferson Davis Vocational Technical School and the Jefferson Davis Academy named directly for the man. But distinction between county and personal names based on the shortened or full form of Davis' first name do not hold up in all cases, for we have a Jefferson Davis Council on the Aging and a Jefferson Davis Electrical Cooperative. But the fact that county services bear his name is still enough to substantiate the commemorative effort. My information is drawn from the Jennings, Louisiana Telephone Directory.

$32 J D H$, p. 18. 
Kentucky, Davis' Alma Mater, a men's dorm is named in honor of the President-Davis Hall-and the lower level of a house he lived in while he was there has been remodeled and turned into a student restaurant and bar called the Jefferson Davis Inn, a less than scholarly but nonetheless collegial honor to Davis. ${ }^{3}$ Two junior colleges are named for Davis: one in Mississippi, and one in Alabama. The Jeff Davis Campus of the Mississippi Gulf Coast Junior College is located in Biloxi very near Beauvoir and doubtless named after Davis because of the proximity, ${ }^{34}$ and there is a Jefferson Davis State Junior College in Brewton, Alabama, its name reflecting an even more patriotic intention by the addition of State. Also offering higher education of a kind are the Jefferson Davis Vocational-Technical School and the Jeff Davis Beauty School, both in Jennings, Louisiana.

There are numerous high schools and elementary schools which have Davis as their guiding light. A few of many examples must suffice. In Houston, southern Texans proudly attend the Jefferson Davis Senior High School, and there is a Jefferson Davis High School in Montgomery, Alabama and a Jeff Davis High in Hazlehurst, Georgia. Receiving instruction in the same subjects, some students in Jennings, Louisiana attend the Jefferson Davis Academy, Incorporated. In Mechanicsville, Virginia, the President must share his honors with the General at the Lee-Davis High School. Moving down the academic scale, we find a Jeff Davis Junior High in Hazlehurst, Georgia and a Jefferson Davis Junior High School in Jacksonville, Florida. Duval County, now synonymous with Jacksonville, appears to be one of the most patriotic school districts in the South, having a Robert E. Lee Senior High, a J.E.B. Stuart Junior High, and a Stonewall Jackson Elementary in addition to the Davis Junior High School. Elementary schools honoring Davis can be found in such Mississippi towns as Biloxi, Long Beach, Hattiesburg (where it is simply listed as Davis Elementary) and Greenwood. And in Jeff Davis County, Georgia, there are the Jeff Davis Elementary and Jeff Davis Middle. And one of those ironies of history and onomastics can be verified at the Jefferson Davis School located at 7701 Grant in New Orleans.

Not every state, though, has a Jefferson Davis school; and it would

33 My thanks are due to Ed Sturgeon of the Greater Lexington Area Chamber of Commerce for this information.

34 This is just one instance where Audrey R. Duckert's injunction does not apply: "Slightly better, but onomastically uninteresting, is the commemorative procession of Washingtons, Jeffersons, Lincolns, and the like-names having little or nothing to do with the places or them that dwell therein" ("Names Forever on the Land," Names, 24:2 [June 1976] , 127). 
be misleading to think so. William W. Peek, assistant to the State Superintendent of Schools, informs me that "none of North Carolina's 2,013 public schools have been named for the late Jefferson Davis." 35 And a few institutions of learning once bearing Davis' name are now no longer in existence. A Jefferson Davis Academy was founded in 1916 at the south end of Warren County, Mississippi, but the school closed in the late 1950's. And in 1971 the Jefferson Davis Elementary School was razed when it was sold to the University of Kentucky. Perhaps Southerners may be consoled by the fact that the Lincoln School in Lexington underwent a similar fate. Still, it seems unlikely that many new schools in the South-elementary or secondary-will be named after Jefferson Davis. The Civil Rights movement and the desire for racial harmony would preclude bestowing a name symbolic of the Confederacy on public institutions (one again recalls Diane Oliver's poignant short story, "Neighbors"). In fact, in the light of Civil Rights some elementary schools which formerly bore the names of white Southern heroes have been changed.

After schools, Davis' name is used most often for highways, roads, and streets. As Secretary of War, Davis was instrumental, as we saw, in planning a route to the West. For his labors he is fondly remembered as "The Father of National Highways" by the Mildred Lee Chapter 1580, U. D. C. of Bakersfield, California. This title befits the man whose name is given to one of the most impressive networks of roads in the country-the Jefferson Davis Highway. Comparable to the Lincoln Highway, the Jefferson Davis (Memorial) Highway is a name given to sections of numerous interconnecting roads running through 15 states and the District of Columbia and traversing the entire southern half of the United States from the Atlantic to the Pacific and continuing up the Pacific Coast from San Diego to the Washington-British Columbia border. The JD Highway also designates a north-south road going from Bowling Green, Kentucky to Biloxi, Mississippi. Unfortunately, though, Highway 68, from Bowling Green to Cadiz and passing through Fairview, Kentucky, is no longer generally known as the Jeff Davis Highway. With the advent of the Interstate Highway System, Kentucky roads seem to have reverted to numbers or parkway names (Blue Grass, Mountains, etc.), thus taking some honor away from Davis. ${ }^{36}$

A small part of the history of this memorial road is worth mention-

35 Personal letter dated March 15, 1977.

36 I wish to thank Mimi C. Lewis of the Kentucky Department of Public Information for notifying me of this. 
ing. In 1913, Mrs. Alexander B. White, President of the U. D. C. thought that such an enterprise would commemorate the man and his cause. Along the Jefferson Davis Highway would "be beautified and historic places on it suitably and permanently marked" and such a road would link "together as far as possible those cities which were capitals of Confederate States." 37 Following Mrs. White, six other women have served on the Jefferson Davis Highway Committee. At first, the U. D. C. had to secure the permission and support of the individual states to name and mark those sections of a previously existing roadway running through their domain as part of the Jefferson Davis Highway.

Each state then adopted a specific resolution to call their part of the continental highway after Jefferson Davis. In 1922, by an act of the Virginia General Assembly, U.S. 1 going from Washington, D. C. through Fredericksburg, Richmond, Petersburg, Lawrenceville, South Hill, Clarkville, and ending at the North Carolina line was to be known as the Jefferson Davis Highway (Chapter 286 "Designating Primary Road No. 1 Jefferson Davis Highway"). Going into North Carolina, the first state to set up permanent markers, U.S. 1 and 15 are part of the Memorial Highway; U.S. 1 going south into South Carolina and connecting such towns as Camden, Columbia, Lexington, and ending at the Georgia line, where we find the Jefferson Davis Memorial Bridge over the Savannah River, is likewise part of the Jefferson Davis Highway. (The President's name is associated with another means of transportation over water; an excursion boat by the name of the Jefferson Davis takes passengers on the Mississippi near Vicksburg.)

In Alabama, sections of U.S. 80, running into Montgomery, have been designated as part of The Jefferson Davis Highway. U.S. 51 from the Tennessee-Mississippi border to Jackson and Highways 49 from Jackson to 90 on the Gulf Coast are also included in the memorial tribute. In Davis' home state, House Concurrent Resolution No. 42 (Chapter 392), March, 1938, officially decrees these designated roadways as "the Jefferson Davis Memorial Highway," dedicated to "the Honorable Jefferson Davis, whose memory is sacred to all Mississippians, [and who] rendered valuable service to his state, nation, as a soldier, as a senator, as a cabinet official and as the only President of the Confederate States of America." Westward through Louisiana, Texas, New Mexico, Arizona, and California, such roads as U.S. 90, 80, 290,59 , and 77 have markers alongside them to proclaim that they also bear the name of Jefferson Davis Memorial Highway. "In 1938, the 
Pacific Coast Highway, in Washington, was designated as that state's part of the Jefferson Davis Highway. This was made part of the state celebration of its fiftieth anniversary in recognition of the services of Davis to the west while Secretary of War." 38 Davis, therefore, is honored not only in one section of the country but across the nation. To the millions of travelers who drive along this vast system of roads Davis may in fact become "the Patron Saint of our road," as the U. D. C. hails him. ${ }^{39}$

Another road commemorating an action in the life of the President of the Confederacy, this time a sad one, is the Jefferson Davis Trail in South Carolina. This route retraces Jefferson Davis' flight from the pursuing Union troops through the Palmetto State during April and May, 1865. The Trail extends from Ft. Mill in the northern section of the state to McCormick near the Georgia line. Unlike the Jefferson Davis Highway, the "route followed by the Trail winds through small towns, farmland, forests, and rolling hills away from interstate traffic." 40 The road follows, parallels, crisscrosses, and winds around such highways as U.S. 21, 378, and 176 and S.C. 51, 246, and 702. Along the way are signs marking the homes Davis visited, the streams he crossed, and the historic buildings he may have seen. The Trail is managed by three state agencies: the South Carolina Department of Parks, Recreation and Tourism, Department of Archives and History, and the State Highway Department.

Turning to shorter roads without much historical significance, we see that numerous towns in the South have named their thoroughfares in honor of Davis. Most prosaic are the streets bearing his name; these are found in such towns as Selma, Macon, and Montgomery (which can boast of an East and West Jefferson Davis Street). There are Jefferson Davis Avenues in Augusta, Austin, Biloxi, and Richmond. In Atlanta, one of the principal arteries of the city is the Jefferson Davis Road. Some other, more interesting variations of Davis' name for roads are the Jefferson Davis Boulevard in Fredericksburg, Virginia, Jefferson Davis Court in Charlotte, Jefferson Davis Circle in Hattiesburg, the Jeff Davis Extension in Oxford, Mississippi, and the Jefferson Davis Parkway in New Orleans, among the Crescent City's nicest streets.

The name and glory of Jefferson Davis is further kept fresh in the memories of Southerners by the parks bearing his name. Doubtless the

\footnotetext{
38 Ibid., p. 4.

39 Ibid., p. 47.

40 Jefferson Davis Trail, a pamphlet distributed by the three South Carolina state agencies résponsible for the Trail.
} 
most famous is the area near Fairview, Kentucky, containing the Jefferson Davis Memorial Shrine. This towering tribute was made possible by the United Daughters of the Confederacy and the Sons of Confederate Veterans. Another illustrious but controversial shrine is to be found at the Jefferson Davis Park, Irwinville, Georgia. It was here that Davis was captured on May 10, 1865, and the park contains a suitable stone marker on the exact spot of Davis' surrender. The park used to be known as "The Jefferson Davis Memorial State Park," but the State of Georgia found it too expensive to keep up and when word was spread that the state wanted to give it up local patriots feverishly protested. ${ }^{41}$ Now the park is run by Irwin County, and it is worth pointing out that this tribute to Davis is less than 100 miles from our current southern President's home of Plains, Georgia. Again, the ironies of history are many. A Confederate Museum is also found in this Jefferson Davis Park.

Still another commemorative location takes its name from an event in Davis' life. Fort Davis, Texas, situated in Jeff Davis County is a national historic site run by the National Park Service. The Fort was established in 1854 by Jefferson Davis when he was Secretary of War. It has been called "the most extensive example of a Southwestern frontier fort," 42 and is a testimony to Davis' farseeing ideas and vigilance in keeping the country strong. Davis was once stationed at this fort as was Robert E. Lee later.

A Jefferson Davis Park can be found in Memphis, located at Riverside and Jefferson, right at the bank of the Mississippi River. It is directly across from the Confederate Park. In Jeff Davis County, Mississippi, we find a Jeff Davis Lake, a name honoring the county that honors the man for whom it is named.

Biographers today readily acknowledge that Davis was a man of loyalty, compassion, and benevolence. His concern for the sufferingsoldiers or servants-is a matter of record. ${ }^{43}$ This part of his character has been rightly preserved in the medical facilities bearing his name. The first such dispensary was located at Beauvoir and called the Jefferson Davis Memorial Home for Confederate Soldiers and Sailors, Their Wives and Widows. One of my students-a fellow at the height of middle age-recalls visiting some Confederate veterans at Beauvoir years ago. Forced to discontinue such services in 1941, Beauvoir today

41 Personal letter from John Algeo, dated March 16, 1977.

42 Quoted in an article on parks found in Family Weekly, a supplement to the Hattiesburg American.

43 See biographical studies by Stroude and Vandiver. 
is a shrine to Davis and the Confederacy.

But a number of hospitals and other health agencies bearing his name serve a vital function in the South. In Mississippi there are two hospitals honoring Davis-the Jeff Davis General Hospital is located in Prentiss, and the Jeff Davis Memorial Hospital is found in Natchez. Honoring the President's memory in Houston is the Jefferson Davis Hospital. In Jennings, Louisiana, the seat of Jeff Davis Parish, there is the Jeff Davis Nursing Home and the Jeff Davis Parish Health Unit, a local clinic.

For the sake of convenience, it may be wise to record here that Davis' name has meant rest to the weary as well as comfort to the sick. There are two hotels I know of named after Davis, the Jefferson Davis Hotel in Montgomery, Alabama and the now demolished Jefferson Davis Hotel at Vicksburg, Mississippi.

There are a number of organizations-fraternal, sororal, and academic-that have honored Jefferson Davis by adopting his name. The Sons of Confederate Veterans have two camps, or local units, in Mississippi named after the President-the Jefferson Davis Camp of the Sons of Confederate Veterans can be found in Biloxi and in Jackson. One of the few northern uses of Davis' name is the Jefferson Davis American Legion Post No. 18 in Centreville, Maryland, a small, picturesque town between Chesapeake Bay and the Delaware line. As a former Secretary of War, Davis seems a logical choice as a patron for a veterans' group; moreover, the influence of the South surely touches this border state. The United Daughters of the Confederacy are doubtless the most zealous promoters of Davis' fame. In his honor, they award the Jefferson Davis Medal to those individuals for their service to the memory of the Confederate cause. As we have seen, the Daughters have been responsible for the development of the Jefferson Davis Highway. Most recently, Davis' place in history is being assured with great accuracy by the Jefferson Davis Association. This is "a nonprofit organization chartered in Texas," specifically centered at Rice University, devoted to collecting Davis' correspondence, personal papers, and works and improving upon and exceeding the ten volumes done in the 1920 's by Dunbar Rowland. To date, two volumes published by the Louisiana State University Press have appeared, and according to a foremost scholar of Southern history in general and Davis in particular, there "may well be an endless series" of Davis' work. 44

The names of presidents have often been given to those aspiring to

44 Vandiver, p. 7. 
their fame. George Washington Carver, the scientist, Thomas Jefferson Abernathy, a historian of Colonial America, or Abraham Lincoln Marovitz, a well-known Chicago judge, are but a few examples. Jefferson Davis himself, as we saw, was named in honor of Thomas Jefferson, and it only seems fitting that as the first and only President of the C. S. A. he should have his name bestowed on future generations. About this practice Davis could have only been pleased, for fleeing from Richmond and Northern troops, Davis stopped near Cokesbury, South Carolina "to get water in front of the brick home of William A. Moore, and it was while there that President Davis gave a small coin to the baby boy who had been named for him, Jefferson Davis Moore." 4 Here we have a man named for a president who becomes a president himself and honors a boy named for him.

For other Southerners who proudly chose to christen their offspring in honor of Davis, the facts speak for themselves. A quick glance at the telephone directories of most Southern cities reveals this habit. In Montgomery, Alabama, there is a Jefferson Davis listed in the February 1969 book; it would be sacrilegious if there had not been at least one such individual in the first capital of the Confederacy. There are three Jeff Davises in the June 1973 Fort Worth phone book and one each in the 1973 and 1977 Gainesville, Florida and Mobile directories, and a Jefferson Davis, Jr. in the Knoxville 1962 white pages. In Austin, Texas 1964 we find a Jeff W. Davis and a Jefferson C. Davis; and a Professor Jefferson C. Davis teaches chemistry at the University of South Florida, according to the 1976 National Faculty Directory. These individuals were fortuitously born Davis but perhaps purposefully named Jefferson or Jeff. Beyond doubt, though, the most patriotic patronymic belongs to a Jefferson Lee Davis who resided in Chattanooga, Tennessee as of September 1973. Of no small consolation to Southerners, too, must be the ironic fact that no fewer than three Jeff Davises resided in Washington, D.C. in 1973-1974.

There is one last comment about the personal use of Jeff Davis. Elsdon Coles Smith is certainly right in pointing out that after the War slaves did not intentionally choose the names Jefferson or Davis. ${ }^{46}$ Yet I wonder if the combination of Jefferson (or Jeff) and Davis is not today a sign of the urban black's own pride in his South, perhaps reflected in the migration of many northern urban blacks to the South.

\footnotetext{
45 Quoted from James P. Sloan, "Jefferson Davis Slept Here-and Here-and Here," pp. 2-3.

46 Elsdon Coles Smith, American Surnames (Philadelphia: Chilton Book Company, 1969), pp. 275-276.
} 
A casual search again through some telephone books from large urban areas-this time from the North-showed many residents of black areas bearing the name of Jeff or Jefferson Davis. In the Chicago White Pages 1973 we find three Jefferson Davises and one Jeff Davis all from black neighborhoods. Similarly, there are Jeff (or Jefferson) Davises residing in black areas in such cities as Cleveland, Detroit, New York, Los Angeles, and that most Caribbean town in America, Miami.

We can draw three conclusions about the incidence of Jefferson Davis' name. One, although it is found primarily in the South, there are some commemorative uses of Davis' name in border and western states. Two, Davis' name, because of the political associations behind it, seems to be in use generally from the very late nineteenth century through the 1950's. Three, his name is most often attached to schools and roads, the Jefferson Davis Highway being the most noticeable, but also can be found for hospitals, hotels, organizations, and parks. Some personal names, too, reflect a commemorative intention.

University of Southern Mississippi

ANS ANNUAL MEETING: December 29 and 30, 1977

The Palmer House, Chicago

Dec. 29, Room 739 1:00 p.m.: Reading of papers

2:50 p.m.: Panel discussion (onomastics and folklore)

3:45 p.m.: Reading of papers

5:30 p.m.: Executive Committee meeting

Parlor E 7:00 p.m.: Annual Dinner

Dec. 30, Room 722 9:00 a.m.: Place-Name Survey meeting

9:40 a.m.: General Business meeting

Room 739 11:00 a.m.: Reading of papers

1:40 p.m.: Panel discussion

(place-name dictionary)

2:35 p.m.: Reading of papers 